\title{
RISK ASSESSMENT FOR EXPERIMENTAL WASTE CONDEMNATION FROM CHICKEN CHALLENGED WITH VARIANT IB VIRAL STRAIN
}

\author{
NADA A. F. EL-SAYED and SAMAH E. ABODALAL
}

\author{
Nadadl@yahoo.com \\ Veterinary Serum and Vaccine Research Institute (VSVRI) \\ El-Seka El-BidaAbbasia, Cairo. Egypt
}

(Manuscript received 23 October 2018)

\begin{abstract}
I nfectious bronchitis virus is an acute and economically important viral disease of chickens. IB is a member of Coronaviridae family it, is an acute disease of respiratory and urogenital tract of chickens. Some IBV strains can cause acute nephritis and urolethiasis associated with high mortality rate in chickens; considering (IBV) which can affect avian and represent a risk for public health, classified as risk group 2 . This study, take place in isolators to detect of experimental waste condemnation after challenge variant IB strain in 3 weeks specific pathogen free vaccinated birds and non-vaccinated control. Samples (kidneys and lungs) were collected for detection of pathological changes. No Histopathological lesions were observed, nor virus were detected following challenge. This work was designed to apply biosecurity and biosafety parameter which including biological waste decontamination and disinfection in order to judge about any residual living virus after challenge test
\end{abstract}

Key words: risk assessment -condemnation of waste -IBV variant strain.

\section{INTRODUCTION}

Infectious bronchitis disease is an acute and economically important viral disease of chickens (Cavanagh, 2005). Infectious Bronchitis virus is a member of Coronaviridae family (Cavanagh and Gelb, 2008), it is an acute disease of respiratory and urogenital tract of chickens (Gelb and Jack wood, 2008). Currently corona viruses are classified into 3 groups based on antigenic and genetic relatedness. IBV is in group 3 of genus coronavirus, together with other coronaviruses from other avian species (Cavanagh, 2003). IBV strains able to infect wide range of epithelial tissues of birds in different ages and species, and sometimes able to infect respiratory epithelial cells and other able to infect reproduction system and proventriculus while group 1 and group 2 comprise mammalian coronaviruses that differ from IBV with respect to genome organization and gene sequence (Liu et al., 2009).Some IBV strains can cause acute nephritis and urolithiasis associated with high mortality rate in chickens (Abdel-Moniem et al., 2006; Susan et al., 2011 Reda et al., 2015).Mortalities in young chickens reached to $30 \%$ and reach to $25 \%$ in less virulent strains which cause less 
respiratory signs. Some virus strains causes' severe kidney damage, urolithiasis and high mortalities, these strains reported as variant strains and cause health problems with high economic losses all over the world (Liu and Kong, 2004).

Waste disposal is all the activities and actions required to manage waste from its inception to its final disposal. (World Health Organization (2004) this includes other things collection, transport, treatment and disposal of waste together with monitoring and regulation. It also encompasses the legal and regulatory framework that relates to waste management encompassing guidance on recycling. The term normally relates to all kinds of waste, the waste management is intended to reduce adverse effects of waste on health, the environment or aesthetics. Waste management practices are not uniform among countries, and sectors (residential and industrial).(World Health Organization (2004).

\section{MATERIALS AND METHODS}

\section{Vaccines:}

IB inactivated vaccine with titer $10^{6.5} \log E_{1} D_{50} / \mathrm{ml}$, was used in this study supplied by VSVRI .

\section{Challenge strain:}

Challenge field isolate (Eg/12197B/2012) was kindly supplied by (VSVRI)it was isolated and identified by using reverse transcription PCR from poultry flock (broiler chicken) at 2012. Virus titration was done using microtiter technique according to OIE (2018) and Calculated according To Reed and Muench (1938).

\section{Specific Pathogen Free-Embryonated Chicken Eggs (SPF-ECE):}

Specific pathogen free (SPF) embryonated chicken eggs (ECE) o were obtained from the SPF production farm, Koum Oshiem, Fayoum, Egypt. Eggs wereincubated at $37^{\circ} \mathrm{C}$ with humidity $56 \%$ till the age of $9-11$ day old and was used for reisolation of IB virus from surface of BSC (bio safety cabinet).

\section{Chicks:}

21-day-old SPF chicks were obtained from SPF poultry farm Koum OushimElFayoum-Egypt. These chicks were kept in Specific isolators where present at animal facility at BSL2 (disposal and contaminant inside BSC).

\section{Animal facility:}

The animal facility is designed, constructed, and maintained to facilitate cleaning and housekeeping. The interior surfaces (walls, floors and ceilings) are water resistant. Penetrations in floors, walls and ceiling surfaces are sealed, including openings around ducts, doors and doorframes, to facilitate best control and proper cleaning. Floors must be slip-resistant, impervious to liquids, and resistant for chemicals. 
Isolators Decondaminated according to biosafety protocols by washing with soap and water and chlorita then fumigated (fumigated twice pre and post entrance of lab animals (birds).

The use of needles and syringes or other sharp instruments in the animal facility is limited to situations blood collection and for collection of organs Sharp instruments must be deconodeminated at sharp box, then at autoclave Inner gloves must be worn to protect against break or tears in the outer suit gloves. Disposable gloves must not be worn outside the change area.

latex gloves should be available. Do not wash or reuse disposable gloves. Inner gloves must be removed and discarded in the inner change room prior to entering the personal shower.

Dispose of used gloves with other contaminated waste after the removal of gloves Persons must wash their hands after handling birds and before leaving the areas where infectious materials manipulated.

All protective clothing must be removed in the dirty side change room before entering the personal shower. Reusable laboratory clothing must be autoclaved before being laundered.

\section{Safety Equipment:}

The following were put in consideration according to BMBL (2015):

1. The wearing of laboratory coats, gowns, and /or uniforms is recommended. Laboratory coats remain in the animal room.

2. Gloves must not be worn outside the animal rooms

3. Gloves and personal protective equipment should be removed in a manner that prevents transfer of infectious materials.

4. Gloves must be worn to protect hands from exposure to hazardous materials. Glove selection should be based on an appropriate risk assessment. Alternatives to latex gloves should be available. Gloves must not be worn outside the laboratory. In addition, BSL-2 laboratory workers should:

a. Change gloves when contaminated, glove integrity is compromised, or when otherwise necessary.

b. Remove gloves and wash hands when work with hazardous materials has been completed and before leaving the laboratory.

c. Do not wash or reuse disposable gloves. Dispose of used gloves with other contaminated laboratory waste. Hand washing protocols must be rigorously followed.

5. Eye and respiratory protection should be used in rooms containing infected birds. 


\section{Disinfectants and soap and waste disposal program}

1. Soap and water

2. Verkon $\mathrm{s}$

3. Clorita

4. Dettol.

5. $\quad 70 \%$ ethanol.

6. Formaldehyde (for fumigation).

\begin{tabular}{|l|c|}
\hline Disinfectants and soap & $\begin{array}{c}\text { Percent used } \\
\text { (\%) }\end{array}$ \\
\hline Soap and water & $1: 10$ \\
\hline Verkon S & $1: 10$ \\
\hline Clorita $®$ & $1: 25$ \\
\hline Dettol $®$ & KMno4:H2O:Formaldahyde \\
\hline Formaldehyde (for fumigation) & $1: 20$ \\
\hline Alcohol & $(1: 1: 2)$ \\
\hline
\end{tabular}

Soap and water were used firstly for washing the animal facility, isolators and laboratory. Then using clorita $®$ then Dettol $®$ and verikon $\mathrm{s}$ for decontamination. Also verikon s used for decontamination of BSC (biosafety cabinet).

$70 \%$ ethanol used according to laboratory biosafety manual WHO (2004) spill cleanup procedures used inside BSC during work and after work.

Fumigation according to laboratory biosafety manual WHO (2004)) using paraform aldehyde.

\section{Sharp container according to (BMBL 2009):}

A sharps container is a hard plastic container that is used to safely disposal of needles and other sharp instruments needles are dropped into the container through an opening in the top should never be pushed or forced into the container, as damage to the container and needle stick injuries may result. Sharps containers should not be filled above the indicated line, usually two-thirds full.

Careful management of needles and other sharps are of primary importance. Needles must not be bent, sheared, broken, recapped, and removed from disposable syringes.

\section{Histopathology:}

Lungs and Kidneys from dead and sacrificed chicks were collected in 10 per cent neutral buffered formalin. The tissues were embedded in paraffin $\left(50-60^{\circ} \mathrm{C}\right)$ and 
sections were cut to 4-6 $\mu$ thickness and stained with haematoxylin and eosin for microscopic examination Nakamura et al. (1991).

All organs after Histopathological examination are collected in sterilized bags for incineration.

\section{Experimental design:}

Three groups of $50 \mathrm{spf}$ chicks Each were used in the study .birds in group(1) were vaccinated via the nasal route with recommended dose while birds in groups (2\&3) were kept as central (+ve\&-ve) respectively.

Three weeks after vaccination, chickens ofgroup 1 and group2 groups were challenged with $100 \mu$ lof (eg\12197ba2d2) challenge virus at dose of 4.0log ${ }_{10} \mathrm{EID}_{50}$ per $0.1 \mathrm{ml}$ administrated via oculonasal route. Group3 was left as unchallenged control. Following challenge, all birds were observed daily for clinical signs Attributable to IB infection following challenge on $3^{\text {rd }}, 5^{\text {th }}$ and $7^{\text {th }}$ days, the trachea, and kidney were collected for pathological examination.

All birds were observed daily for clinical signs attribute to IB infection.

All equipment used for collecting organs like (scalpel, forceps, petri dish) were washed and disinfected firstly, then sterilized incinerator (stainless steel and glass ware).

Collected organs after pathological examination were disinfected,packed in incineration bag and labeled then subjected for complete incineration.

Swaps were taken after decontamination from isolator, challenge room, BSC biosafety cabinet from all corners and from used instruments after sterilization and SPF egg (10 \sample) were inoculated with $0.1 \mathrm{ml} /$ egg from diluted swaps in $2 \mathrm{ml}$ physiological saline.

\section{RESULT AND DISCUSSION}

The number of high level biosafety laboratory had a rapid increase due to the occurrence and spread of highly pathogenic infectious disease. The objective of the high level biosafety laboratory is pathogenic microorganism with high human and environmental risks. Thus it becomes a "hot spot " for the Worldwide governments how to avoid these environmental effects of pathogenic microorganisms. Q.G. Wang et al., (2012).

The high level biosafety laboratory had a rapid increase due to the occurrence and spread of highly pathogenic infectious disease. For the environmental risk assessment of laboratory biosafety, pathogenic microorganisms are the most important determining factor influencing the bio-hazard assessment and environmental risk assessment (Mikkelsen T. (2003) and Zhao G., et al., 2008). 
Awareness of the routes of transmission for the natural human disease is helpful in identifying probable routes of transmission in the laboratory and the potential for any risk to the public health.

Workers are the first line of defense for protecting themselves, others in the laboratory, and the public from exposure to hazardous agents. Protection depends on the conscientious and proficient use of good microbiological practices and the correct use of safety equipment. A risk assessment should identify any potential deficiencies in the practices of the laboratory workers. Carelessness is the most serious concern, because it can compromise any safeguards of the laboratory and increase the risk for coworkers. Training, experience, knowledge of the agent and procedure hazards, good habits, caution, attentiveness, and concern for the health of coworkers are prerequisites for a laboratory staff in order to reduce the inherent risks that attend work with hazardous agents. Not all workers who join a laboratory staff will have these prerequisite traits even though they may possess excellent scientific credentials. Laboratory directors or principal investigators should train and retrain new staff to the point where aseptic techniques and safety precautions become second nature. (Lennette.,1973).

Sharps waste is of great concern in developing and transitional regions of the world. Factors such as high disease prevalence and lack of health care professionals amplify the dangers involved with sharps waste, and the cost of newer disposal technology makes them unlikely to be used (Simonsen,. Et al; 1999). Improper sharps management is a major factor involved in what is categorized as unsafe injections (Dziekan, et al; 2003)

Table 1. summarized the used disinfectant object and reisolation of IB virus after experimental trials.

\begin{tabular}{|c|c|c|c|c|}
\hline \multirow[t]{2}{*}{ Disinfectants } & \multicolumn{4}{|c|}{ Objects } \\
\hline & BSC & Isolator & Lab room & Animal room \\
\hline Soap and water & -ve & -ve & -ve & -ve \\
\hline Verkon s & -ve & Not applied & Not applied & Not applied \\
\hline Clorita @ & -ve & -ve & -ve & -ve \\
\hline Dettol @ & -ve & -ve & -ve & -ve \\
\hline $\begin{array}{l}\text { Formaldehyde(for } \\
\text { fumigation) }\end{array}$ & Not applied & Not applied & -ve & -ve \\
\hline Alcohol & -ve & Not used & Not used & Not used \\
\hline
\end{tabular}

$\mathrm{Nb}$ :-ve no virus detected by reisolation.

No virus detected by re isolation after using different types of disinfection 


\section{IN CONCLUSION}

Results displayed in table1revealed that waste contamination are sharps containers filled above the indicated line, usually two-thirds full. Unlocking and unsalable sharps containers, so that sharps easily penetrate through the sides. A feedback report on finding had been provided for biosafety committee and authorities for target training for responsible persons.

\section{REFERENCES}

1. Abdel-Moneim, A.S; El-Kady, M.F; Ladman B.S \& Gelb J. Jr: 2006. S1 gene sequence analysis of a nephropathogenic strain of avian infectious bronchitis virus in Egypt. Virology. J 3:78.

2. Alvarado, I.R.; Villegas, P.; El-Attrache, J. \&Brown, T.P. 2003. Evaluation of the protectionconferred by commercial vaccines against theCalifornia 99 isolate of infectious bronchitisvirus. Avian Dis. 47: 1298-1304.

3. BMBL. 2009. Biosafety in Microbiological and Biomedical Laboratoriesfith edition .

4. Cavanagh, D andGelb,J(2008): J. Infectious bronchitis. In: Saif YM, FadlyAM.

5. Cavanagh, $\mathrm{D}(2005)$ : Coronaviruses in poultry and other birds. Avian Pathology 2005; 34:439-448.

6. Cavanagh, D. 2003. Severe acute respiratory syndrome vaccine development: experiences of vaccination against avian infectious bronchitis coronavirus. Avian Pathology 2003; 32:567-82

7. Cavanagh, D., \& Gelb, J. Jnr. 2008. Infectious Bronchitis", Diseases of Poultry, 4, Blackwell, 117- 135

8. Cook, J.K.A.; Orbell, S.J.; Woods, M.A. \& Huggins M.B. 1999. Breadth of protection ofthe respiratory tract provided by different liveattenuated infectious bronchitis vaccines against challenge with infectious bronchitis virus of heterologous serotypes. Avian Pathol. 28:477-

9. Dziekan G, Chisolm D, Johns B, Rovira J, Hutin Y. 2003. The cost-effectiveness of policies for the safe and appropriate use of injection in healthcare settings. Bulletin of the World Health Organization, 81(4).

10. Lennette EH. 1973. common sense in the laboratory: recommendations and priorities. Biohazards in biological research. Proceedings of a conference held at the Asilomar conference center; 1973 Jan 22-24; p. 353.

11. Liu, S.W. \& Kong, X.G. 2004. A new genotypeof nephropathogenic infectious bronchitis viruscirculating in vaccinated and non-vaccinatedflocks in china. Avian Pathol. 33:321-327 
12. Mikkelsen T. 2003. Investigation of airborne foot-and-mouth disease virus transmission during low-wind conditions in the early phaseof the UK 2001 epidemic. Atmos. Chem. Phys. Discuss. 2003;3: 677.

13. Nakamoura, K.; Cook, J.K.A.; Otsuki, K.;Huggins, M.B; \& Frzaier, J.A. 1991. Comparative study of respiratory lesion in twochicken lines of different susceptibility infectedwith infectious bronchitis virus: Histology,ultrastructure and immunohistochemistry. Avian Patholol. 23:631-641.

14. OIE. 2018. OIE terrestrial manual chapter 2.3.2 infectious bronchitis virus page 3-4.

15. Q.G. Wang*, F. Ding, S.B Li, and X.H. Zhao. 2012. Advance in Environmental Risk Assessment of High LevelBiosafety LaboratoryProcedia Environmental Sciences 13 (2012) 1458 - 1461.

16. Reda, R. Fathy, El-boraay, I. M., El-shorbagy, M. A., Susan, SEL mahdy. 2015. a survey on presence of new strains of infectious bronchitis virus in some chicken farms of Egypt delta provinces during 2014benha vet. Med journal,vol.28,no.2:248-262,2015

17. Simonsen, L. Kane, A. Lloyd, J. Zaffran, M. Kane, M. 1999. Unsafe injections in the developing world and transmission of blood borne pathogens: a review. Bulletin of the World Health Organization, 77(10)

18. Susan, S. El-Mahdy; Y.A., Soliman\& M.M. El-Hady. 2011. Preparation and evaluation ofMaster Seed of infectious bronchitis vaccine.

19. Thompson, G.; Mohammed, H.; Buaman, B. \&Nagi, S. 1997. Systemic and local antibodyresponses to infectious bronchitis virus in chickens inoculated with infectious bursaldisease virus and control chickens. Avian Dis.41:519-527.

20. WHO World Health Organization. 2004. Proposed agenda to evaluate the risks and benefits associated with using needle-removing devices. Switzerland.

21. Worthington. K.J. ; Savage. C.; Nayloc, C.K.; Wijmenga. W. \& Jones R.C. 2004. An RT-PCR survey of infectious bronchitis virus genotypes inthe UK and Selected European Countries between 2002 and 2004 and the results from avaccine trial in proceedings of the IV symposiumon avian corome and pneumovirus infections (pp,(125-133). Rauischholzhausen. Germany.

22. Zhao G, Wang G, Fang H, Zou J. 2008. Environmental risk assessment of foot and mouth disease virus research in biosafety leve-3laboratory. Chinese Pharmaceuticl affairs 2008; 22(11):971-4 (in Chinese) 


\section{تقدير المخاطر الناتجه من نفايات الدواجن بعد اختبار التحدي}

بعتره فيروس التهاب الشعب المعدي المغايره

\section{ندي عادل فتحي و سماح السيد علي ابو دلال}

معهُ بحوث الامصال و اللقاحات البيطرية ، العباسية ، القاهرة

يعد مرض فيروس الالتهاب الثعبي المعدي مرض حاد ومهم اقتصاديا في مجالات الانتاج

الداجني وهذا الفيروس عضو من عائله الكورونا فيريدي و ويعد مرض حاد بالجهاز التنفسي

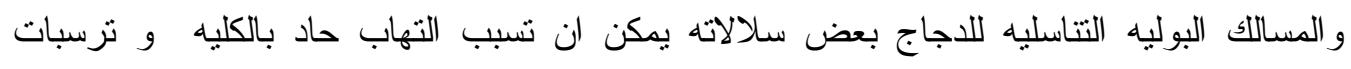

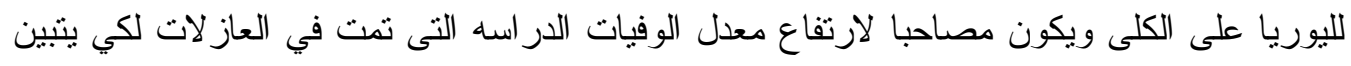

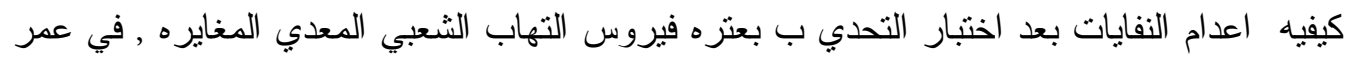

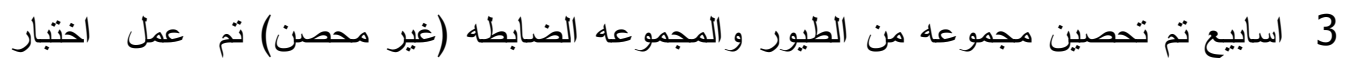

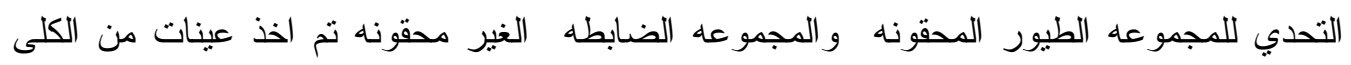
و الرئتين لـعرفه التغيرات البيولوجيه التي تحدث داخل الطائر من هذا الفيرس بعد اختبار التحدي مني

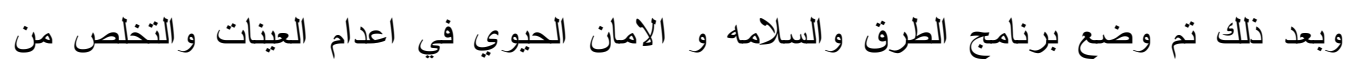
الادوات مع بيان انو اع معدات الوقايه الثخصيه التي يتم استخدامها و كيفيه التخلص من ونديه الطيور النافقه مما يحد من انتشار المرض عمل تبان لقيم للنتائج. 
